\title{
Residential Buildings Thermal Performance to Comply With the Energy Conservation Code of Saudi Arabia
}

\author{
Faris A. AlFaraidy \\ Northern Border University \\ Arar, Saudi Arabia \\ falfaraidy@gmail.com
}

\author{
Salah Azzam \\ Northern Border University \\ Arar, Saudi Arabia \\ salah.alazzam@gmail.com
}

\begin{abstract}
About half of the total generated electricity in Saudi Arabia (SA) is consumed for the air conditioning of residential buildings. To reduce this burden on the economy as outlined by the country's 2030 vision, the implementation of the Saudi energy conservation code (SBC602) needs to be enforced. This code divided KSA into three climate zones with maximum overall heat transfer coefficients. This study aims to facilitate the use of thermal insulation by analyzing optimum thermal insulation thickness for each zone and calculate the payback period of initial insulation costs. Three cities were selected to represent the three climate zones, Riyadh, Arar, and Turaif. The codecompliant thermal insulation thickness is calculated using these variables: thermal properties of three insulation materials, overall heat transfer coefficients, and three insulated wall structures. It is concluded that external insulation and finish system utilizing polyurethane is the most feasible option with the best thermal performance. Polyurethane thicknesses are ranging from $45 \mathrm{~mm}$ to $65 \mathrm{~mm}$, wall widths are ranging from $250 \mathrm{~mm}$ to $320 \mathrm{~mm}$, while the overall costs are ranging from 20.02 to $24.57 \mathrm{US} \$ \mathrm{~m}^{2}$. This system is used to conduct a comparison between energy-efficient-building and base-case-building in terms of cooling loads and electrical consumption using hourlyanalysis-program (HAP) with international weather data. The simulated annual savings in energy consumption for the three zones are $67.4 \%, 66.56 \%$, and $67.91 \%$. The economic analysis shows promising payback years, which are 3.1, 3.9, and 4.3 for zone one, zone two and zone three respectively.
\end{abstract}

Keywords-energy efficiency code; thermal insulation; residential buildings

\section{INTRODUCTION}

The demand for electricity is growing rapidly in SA due to increase in population and building construction. It grew 33\% over the last 5 years [1]. Even before the 2030 vision, which outlined the future for SA beyond oil and gas, the government considered an imperative strategy to lower carbon economy and energy efficiency as a major topic for all decisions related to the increase in demand for fuel and feedstock [2]. It is estimated that 2.32 million new houses are to be built by 2020 in order to meet the demands of the growing population [3]. Buildings are the largest energy consumer, with $50.36 \%$ of total consumption in 2016 [4]. Furthermore, the consumption in governmental and commercial sectors makes total building consumption in residential, commercial and governmental sectors about $80.6 \%$. Table I shows the total share of building sector among other sectors.

TABLE I. ELECTRICITY CONSUMPTION IN SA (2016)

\begin{tabular}{|c|c|c|c|}
\hline & Annual $\left(\mathbf{1 0}^{\mathbf{3}} \mathbf{G W h}\right)$ & \multicolumn{2}{|c|}{ Share in total \% } \\
\hline Residential & 144 & 50.4 & \multirow{2}{*}{80.6} \\
\cline { 1 - 3 } Commercial & 47 & 16.4 & \\
\hline Government & 39 & 13.8 & \multirow{2}{*}{19.4} \\
\hline Industrial & 45 & 15.8 & 100 \\
\hline Others & 10 & 3.7 & 100 \\
\hline Total & 286 & \multicolumn{2}{c}{} \\
\hline
\end{tabular}

In developing buildings in SA, the appropriate selection of construction materials would reduce energy consumption for cooling load by $59 \%$ [5]. A substantial saving in annual energy subsidies can be achieved by the government if it promotes energy efficiency investments and incentives [6]. Author in [7] found that the payback periods for Riyadh city were 2.3-2.7 years for polystyrene and 2-2.5 for polyurethane. A recent study showed that air conditioning has the largest segment of power consumption [8]. The statistics on this issue indicate that $60 \%$ of the monthly consumption is caused by air conditioning. Author in [9] studied the electrical consumption relation with the climate zones of SA. In Riyadh city (climate zone 1) the AC consumption is $70 \%$, in Tabuk (climate zone 2) the AC consumption is $63 \%$ and in Abha (climate zone 3) the $\mathrm{AC}$ consumption is $49 \%$. Therefore, SA has developed regulations regarding building energy efficiency to achieve energy efficient buildings which became mandatory in 2010 [10]. This code was formulated based on the International Energy Efficiency Code (2003) and the American Society of Heating, Refrigerating, and Air-Conditioning Engineers (ASHRAE). Hence, Saudi Standard Metrology and Quality Organization issued standard No. 28793/2014 Thermal Transmittance Values for Residential Buildings [11].

\section{A. Research Problem}

More than $71 \%$ of the residential buildings in SA are not energy efficient and lack the use of thermal insulation [12]. SA is a hot area and most of its terrain consists of arid desert or 
barren landforms. Therefore there is an extensive use of air conditioning in buildings. Interviews with concerned people in the region, like contractors, design engineers, consultants, officials, etc. showed that the reason behind the lack of thermal insulation is mainly its high initial cost, while some interviewers pointed out their lack of knowledge regarding the right architectural installation of thermal insulation. This study aims at facilitating the use of thermal insulation as outlined by SBC602 and to study economic feasibility and energy savings.

\section{B. Hourly Analysis Program (HAP)}

It is common to use cooling degree-days to estimate the annual thermal loads as the summation of temperature differences between the building exterior and interior temperatures. As a building's base temperature typically varies throughout the year, the accuracy of degree-days method was very ambiguous and therefore not helpful to energy experts who need robust tools and clear guidance. Finally, the combined effect of these problems leads to low accuracy in degree-day calculations. Computer based programs are recently used to design heating ventilation and air conditioning (HVAC) systems and simulate their energy consumption. HVAC presents accurate and reliable methods for engineers and planners. For instance, authors in [13] conducted computer simulations and energy performance studies for a typical residential building and prevalent conditions in the Gulf region. One of these computer programs is Hourly Analysis Program (HAP). HVAC loads are designed using HAP to calculate thermal loads and to simulate energy consumption. It uses ASHRAE-endorsed heat transfer method using detailed 8,760 hour by-hour simulation techniques for energy analysis. It computes hourly cooling loads based on simulated outside temperatures and used historical temperatures logs for many years to give relatively accurate estimation of annual energy consumption. Besides, it calculates all heat gains including internal heat gains. It requires scheduling on hourly basis the occupancy of people inside the building, schedules for lighting and home appliances.

\section{Design Weather Data}

For the purposes of SBC 602, Saudi Arabia is divided into 3 climate zones. The selected cities represent those zones (Table II). Weather design data for the 3 cities were obtained from ASHRAE climatic design conditions [14]. Annual cooling and enthalpy design conditions, design dry bulb and wet bulb temperatures have been obtained for the 3 cities.

TABLE II. SELECTED CITIES REPRESENTING THE CLIMATIC ZONES

\begin{tabular}{|c|c|c|}
\hline City & Region & Climate Zone \\
\hline Riyadh & Southern region & I \\
\hline Arar & Northern region & II \\
\hline Turaif & Northern Region & III \\
\hline
\end{tabular}

\section{International Weather for Energy Calculations (IWEC 2)}

The weather data for the three cities are derived from ASHRAE data base. Integrated surface hourly (ISH) weather data were archived at the USA National Climatic Data Center. For the selected cities, the ISH database contains 12 years of hourly loggings of dry-bulb temperature, wet pulp temperatures and solar radiation [15].

\section{E. Base-Case Building}

A typical residential building is studied in each of the three cities. Most buildings are poorly energy efficient and lack the use of thermal insulation. Building's details were used as inputs for later examination using HAP for building HVAC design and simulation. These details included building drawings, elevations, building structure, external walls and thermal insulations. The base-case building characteristics including architectural and HVAC status are summarized in Table III.

TABLE III. ENERGY CONSERVATION REQUIREMENTS OF SBC 602

\begin{tabular}{|c|c|c|}
\hline Item & $\begin{array}{c}\text { Energy efficient } \\
\text { building }\end{array}$ & $\begin{array}{c}\text { Base-case } \\
\text { building }\end{array}$ \\
\hline General & \multicolumn{2}{|c|}{$\begin{array}{l}\text { Front elevation facing South West, rectangular } \\
\text { shape, low height building consisting of two } \\
\text { floors, } 300 \mathrm{~m}^{2} \text { area, floor to floor height } 3.5 \mathrm{~m}\end{array}$} \\
\hline Occupancy & \multicolumn{2}{|l|}{7 people } \\
\hline \multirow{2}{*}{ Wall and roof $U$} & $\begin{array}{c}\text { Wall: } 0.342 / 0.387 / 0.453 \text { for } \\
\text { zones } 1,2,3\end{array}$ & 2.180 \\
\hline & $\begin{array}{c}\text { Roof: } 0.202 / 0.238 / 0.273 \text { for } \\
\text { zones } 1,2,3 \\
\end{array}$ & 2.449 \\
\hline Door U & 2.839 for all zones & 5.3 \\
\hline Window Overall U & 2.668 for all zones & 5.048 \\
\hline Window type & $\begin{array}{l}\text { Aluminum frame with } \\
\text { thermal breaks or PVC }\end{array}$ & Aluminum frame \\
\hline Internal shading & $\begin{array}{l}\text { Vertical blinds/drapes } \\
\text { closed weave light color. }\end{array}$ & $\begin{array}{c}\text { Drapes-open } \\
\text { Weave }- \text { medium }\end{array}$ \\
\hline Glass type & $\begin{array}{l}\text { Double glazed with } 12 \mathrm{~mm} \\
\text { air space }\end{array}$ & $6 \mathrm{~mm}$ single glass \\
\hline External Color & Light & Medium \\
\hline SHGC & For all zones $\leq 0.25$ & 0.5 \\
\hline SRI & Light color with $S R I \geq 50$ & $\begin{array}{l}\text { medium color } \\
\text { SRI }=25\end{array}$ \\
\hline $\begin{array}{l}\text { Water absorption for } \\
\text { insulation materials }\end{array}$ & $\leq 0.3 \%$ & NA \\
\hline Continuous insulation & $\begin{array}{l}\text { Continuous across all } \\
\text { building envelope }\end{array}$ & NA \\
\hline Ventilation & $54.5 \mathrm{~L} / \mathrm{s}$ & Same \\
\hline Infiltration in fenestration & $\leq 1.5 \mathrm{~L} / \mathrm{s} / \mathrm{m}^{2}$ & Same \\
\hline Infiltration in foors & $\leq 2.5 \mathrm{~L} / \mathrm{s} / \mathrm{m}^{2}$ & Same \\
\hline Lighting power density & $\begin{array}{c}10 \mathrm{~W} / \mathrm{m}^{2} \text { ground floor, } 6 \\
\mathrm{~W} / \mathrm{m}^{2} \text { first floor }\end{array}$ & same \\
\hline Equipment power density & $\begin{array}{l}2.0 \mathrm{~kW} \text { ground floor, } 1.0 \mathrm{~kW} \\
\text { first floor }\end{array}$ & same \\
\hline Vertical fenestration area & $\leq 25 \%$ of the wall area & No Restriction \\
\hline EER & $E E R \geq 11$ & No Restriction \\
\hline
\end{tabular}

\section{F. Building Energy Conservation Requirements (SBC 602)}

Saudi Building Code Energy Conservation Requirements SBC 602 has minimum performance for the design of energyefficient buildings and structures. These requirements address the design of energy-efficient building envelopes. The minimum performance requirements for energy efficient buildings in comparison with the base case building are summarized in Table III.

\section{ARCHITECTURAL INSTALLATION OF THERMAL INSULATION}

\section{A. Wall Structure I: Double Wall System (DWS)}

DWS requires the constructing of external wall besides the internal wall, while thermal insulation is inserted in the wall cavity. Hollow concrete blocks are conventional architectural 
style in the region with external finish of decorative profile painting as shown in Figure 1.

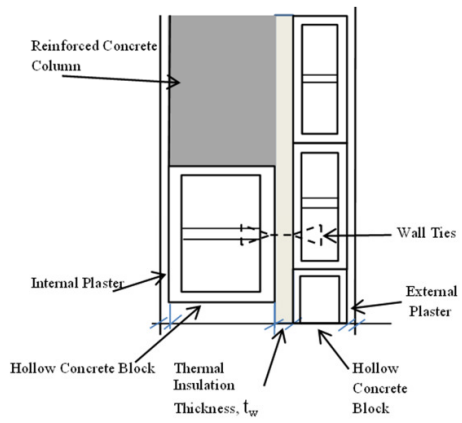

Fig. 1. Wall type I: DWS

\section{B. Wall Structure II: External Insulation and Finish System (EIFS)}

In this wall type, insulation materials are installed on the external wall surface and cladded by mechanical means as illustrated in Figure 2. Many cladding materials may be used like stone, marble, granite, ceramics and fiber cement boards. The use of fiber cement board in external insulation system might be applied according to [16]. In this regard, the fiber cement board should be free of asbestos [17], strong, flat and flexible board composed of Portland cement, refined ores and reinforced cellulose fiber as main materials.

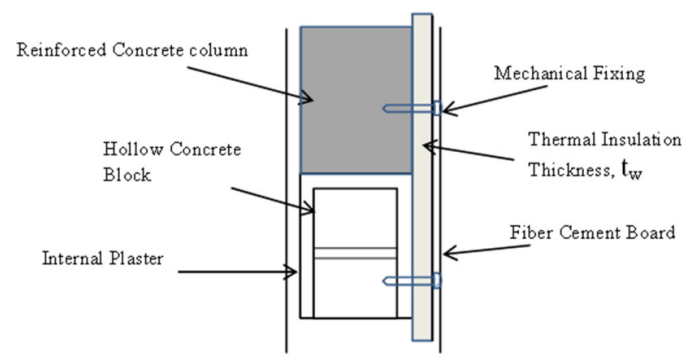

Fig. 2. Wall type II: EIFS

EIFS should be compliant with international standards and specifications related to surface roughness, density, moisture movement, bending strength, impact resistance, shrinkage and expansion and resistance to fungus growth [18]. Also, it should be compliant with safety standards and fire resistant for 2 hours of fire for interior or exterior wall system with no failure [19].

\section{Wall Structure III: Internal Insulation and Finish System (IIFS)}

In this system, the thermal insulation material is installed on the interior part of the wall. It uses fiber cement boards to build the internal partition while insulation material is installed behind it using mechanical fixing. The main difference between EIFS and IIFS is that IIFS usually has thermal bridges in the roof slabs and the columns that are installed inside the building will restrict the selection of insulation material to be highly fire resistant like rock wool as shown in Figure 3.

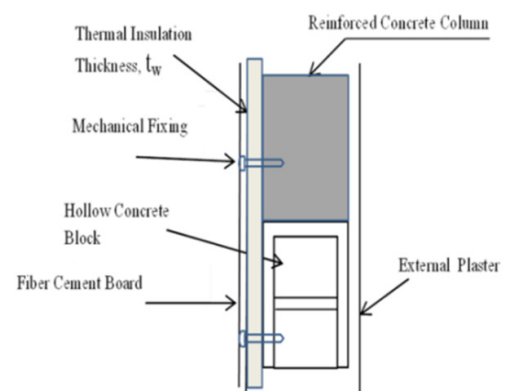

Fig. 3. Wall type III: IIFS

\section{DESIGN HVAC LOADS AND ENERGY CONSUMPTION}

\section{A. Program Input Data}

A brief summary of input data consisting of weather data, heat transfer coefficient for wall structure, roofs, windows, doors, fenestration, ventilation, and infiltration, is listed in Table IV.

TABLE IV. BASIC ASSUMPTION DATA FOR ENERGY EFFICIENT BUILDING FOR HAP 4.9

\begin{tabular}{|c|c|c|c|}
\hline \multirow{3}{*}{ Weather Data } & Arar & \multirow{2}{*}{\multicolumn{2}{|c|}{$\begin{array}{c}\text { SAU_ARAR_403570_IW2.CSV } \\
\text { SAU_TURAIF_403560_IW2 }\end{array}$}} \\
\hline & Turaif & & \\
\hline & Riyadh & \multicolumn{2}{|c|}{$\begin{array}{c}\text { SAU_RIYADH } \\
\text { OBS(OAP)_404380_IW2 }\end{array}$} \\
\hline \multirow{4}{*}{$\begin{array}{l}\text { Indoor } \\
\text { conditions }\end{array}$} & \multicolumn{2}{|c|}{$\begin{array}{l}\text { Summer dry bulb } \\
\text { temperature }\end{array}$} & $24.0^{\circ}$ \\
\hline & \multicolumn{2}{|c|}{ Summer relative humidity } & $50 \%$ \\
\hline & \multicolumn{2}{|c|}{ Winter dry bulb temperature } & $21.0^{\circ} \mathrm{C}$ \\
\hline & \multicolumn{2}{|c|}{ Winter relative humidity } & $30 \%$ \\
\hline \multirow[b]{2}{*}{$\begin{array}{l}\text { Ventilation } \\
\text { requirements }\end{array}$} & \multicolumn{2}{|c|}{ Occupant ventilation } & $2.5 \mathrm{~L} / \mathrm{s} /$ person \\
\hline & \multicolumn{2}{|c|}{$\begin{array}{c}\text { Floor ventilation } \\
\text { requirements }\end{array}$} & $0.30 \mathrm{~L} /\left(\mathrm{s} \times \mathrm{m}^{2}\right)$ \\
\hline $\begin{array}{l}\text { Overhead } \\
\text { lighting }\end{array}$ & \multicolumn{2}{|c|}{ Recessed (vented) } & $10.00 \mathrm{~W} / \mathrm{m}^{2}$ \\
\hline $\begin{array}{c}\text { Ballast } \\
\text { multiplier }\end{array}$ & & & 0.87 \\
\hline \multirow{2}{*}{ Occupancy } & \multicolumn{2}{|c|}{ Latent heat: 7.0 People } & $133.3 \mathrm{~W} /$ person \\
\hline & \multicolumn{2}{|c|}{ Sensible heat: 7.0 People } & $86.5 \mathrm{~W} /$ person \\
\hline Infiltration & \multicolumn{2}{|c|}{$\begin{array}{l}0.5 \mathrm{ACH} \text { (air volume } \\
\text { change per hour) }\end{array}$} & $151.5 \mathrm{~L} / \mathrm{s}$ \\
\hline \multirow{3}{*}{ Floor type } & \multicolumn{2}{|c|}{ Total floor U-Value } & $1.500 \mathrm{~W} /\left(\mathrm{m}^{2} \times{ }^{\circ} \mathrm{K}\right)$ \\
\hline & \multicolumn{2}{|c|}{ Exposed perimeter } & $80.0 \mathrm{~m}$ \\
\hline & \multicolumn{2}{|c|}{ Edge insulation R-Value } & $0.40\left(\mathrm{~m}^{2} \times{ }^{\circ} \mathrm{K}\right) / \mathrm{W}$ \\
\hline Supply fan & & & $1721 \mathrm{~L} / \mathrm{s}$ \\
\hline \multirow{3}{*}{$\begin{array}{l}\text { Window, double } \\
\text { glass } 12 \mathrm{~mm} \text { air } \\
\text { space }\end{array}$} & \multicolumn{2}{|c|}{$\begin{array}{l}\text { Frame PVC/Vinyl vertical } \\
\text { blinds }\end{array}$} & $\mathrm{U}: 2.594 \mathrm{~W} / \mathrm{m}^{2} \times{ }^{\circ} \mathrm{K}$ \\
\hline & \multicolumn{2}{|c|}{$\begin{array}{l}\text { Frame: wood/Vertical blinds } \\
\text { / roller shades light } \\
\text { translucent/Drapes closed } \\
\text { weave light. }\end{array}$} & $\mathrm{U}: 2.67 \mathrm{~W} / \mathrm{m}^{2} \times{ }^{\circ} \mathrm{K}$ \\
\hline & \multicolumn{2}{|c|}{$\begin{array}{l}\text { Frame: Aluminum with } \\
\text { thermal breaks Vertical } \\
\text { blinds }\end{array}$} & $\mathrm{U}: 2.371 \mathrm{~W} / \mathrm{m}^{2} \times{ }^{\circ} \mathrm{K}$ \\
\hline
\end{tabular}

\section{B. Calculation of Minimum Thermal Insulation Thickness to Comply with SBC 602}

A basic heat transfer equation is formulated to determine an overall heat transfer coefficient $\left(\mathrm{U}_{\text {overall }}\right)$ for walls, roofs, windows and doors. This equation aims to find the overall heat transfer coefficient for building's envelope: 


$$
\mathrm{U}_{\text {overall }}=\frac{1}{\left(\frac{1}{h i}+\sum_{i=1}^{n}\left(\frac{x i}{k i}\right)+\frac{1}{h e}\right)}
$$

where $k$ is the thermal conductivity of the material $(\mathrm{W} / \mathrm{m} \cdot \mathrm{K}), x_{i}$ is the thickness of material in composite wall $i(\mathrm{~m}), h_{e}$ is the individual convection heat transfer coefficient for outside air film $\left(\mathrm{W} / \mathrm{m}^{2} \cdot \mathrm{K}\right), h_{i}$ is the individual convection heat transfer coefficient for inside air film $\left(\mathrm{W} / \mathrm{m}^{2} \cdot \mathrm{K}\right)$, and $\mathrm{n}$ is the wall layer number.

The wall insulation thickness and roof insulation thickness can be calculated by (2) and (3) respectively:

$$
\begin{gathered}
t_{w}=k_{w} \cdot\left[\left(1 / U_{W \text {-code }}\right)-\left(1 / h_{i}\right)-\left(1 / h_{o}\right)-\sum_{i=1}^{n} \frac{x_{i}}{k_{i}}\right] \\
\mathrm{t}_{r}=k_{r} \cdot\left[\left(1 / U_{R-\text { code }}\right)-\left(1 / h_{i}\right)-\left(1 / h_{e}\right)-\sum_{i=1}^{n} \frac{X_{i}}{k_{i}}\right]
\end{gathered}
$$

where $t_{w}$ is the minimum wall insulation thickness in compliance with the code, $k_{w}$ is the thermal conductivity of the wall insulation material, $t_{r}$ is the minimum insulation thickness for roof in compliance with the code, $k_{r}$ the thermal conductivity of the roof insulation material, $U_{W \text {-Code }}$ is the wall overall heat transfer coefficient $\left(\mathrm{W} / \mathrm{m}^{2} . \mathrm{K}\right)$ as defined by SBC 602 (Table IV), $U_{R \text {-Code }}$ is the wall overall heat transfer coefficient $\left(\mathrm{W} / \mathrm{m}^{2} . \mathrm{K}\right)$ as defined by SBC 602 (Table IV). Three insulation materials are selected for this study for their thermal performance and availability in the market. Their physical and

\begin{tabular}{|c|c|c|c|c|c|c|}
\hline Material & \multicolumn{2}{|c|}{ Polystyrene } & \multicolumn{2}{|c|}{ Polyurethane } & \multicolumn{2}{|c|}{ Rockwool } \\
\hline Use & Wall & Roof & Wall & Roof & Wall & Roof \\
\hline Cost $^{*}\left(\mathrm{SAR} / \mathrm{m}^{3}\right)$ & 385 & 415 & 400 & 440 & 400 & 460 \\
\hline $\begin{array}{c}\text { Thermal conductivity } \\
\mathbf{K}(\mathbf{W} / \mathbf{m} . \mathbf{K})\end{array}$ & 0.029 & 0.028 & 0.02 & 0.02 & 0.04 & 0.04 \\
\hline Specific Heat (J/kg) & 1280 & 1280 & 1590 & 1590 & 840 & 840 \\
\hline Density $\left(\mathrm{Kg} / \mathrm{m}^{3}\right)$ & $26-28$ & $32-35$ & 28 & 35 & 100 & 150 \\
\hline Appearance & \multicolumn{2}{|c|}{ rigid boards } & \multicolumn{2}{|c|}{ rigid boards } & \multicolumn{2}{|c|}{ bats } \\
\hline
\end{tabular}
thermal properties are listed in Table V.

TABLE V. PROPERTIES AND COSTS OF INSULATION MATERIALS

\section{RESULTS AND DISCUSSION}

Figures 4-9 show the weather design and simulation for the three studied cities. The simulated annual temperature profiles, dry bulb and wet pulp are shown in Figures 4-6. The simulated solar profiles and maximum solar heat gains are shown in Figures 7-9.

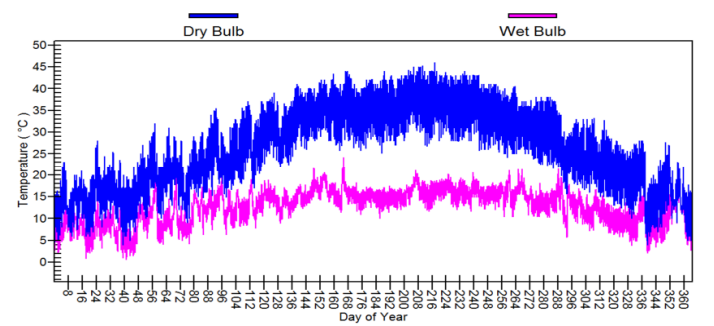

Fig. 4. HAP annual simulated temperature profile for Riyadh (zone 1)

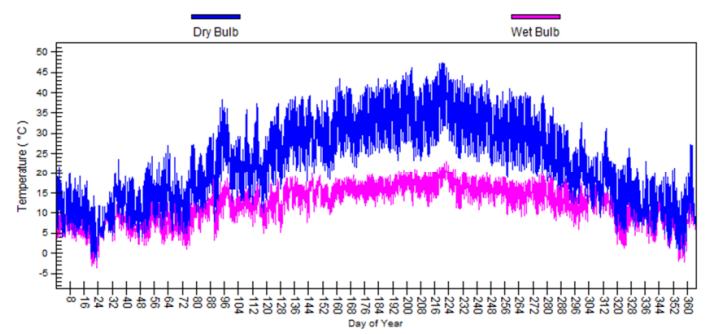

Fig. 5. HAP annual simulated temperature profile for Arar (zone 2)

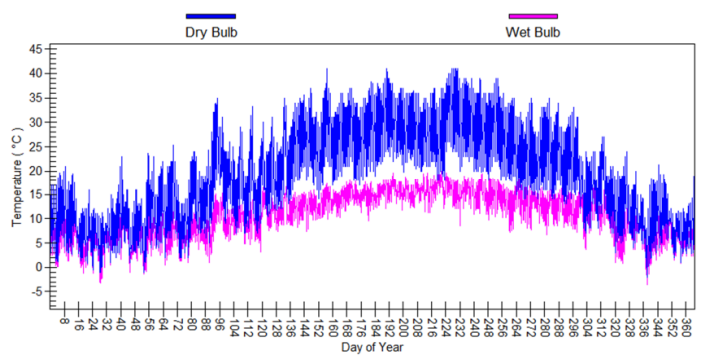

Fig. 6. HAP annual simulated temperature profile for Turaif (zone 3)

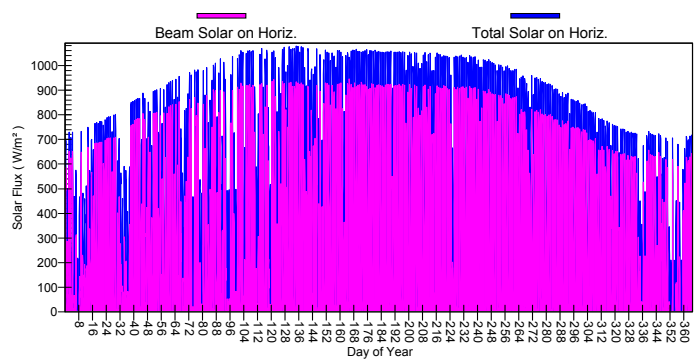

Fig. 7. HAP simulated solar profile for Riyadh (zone 1), weather file IWEC2 SAU_RIYADH-OBS (OAP)_404380_IW2

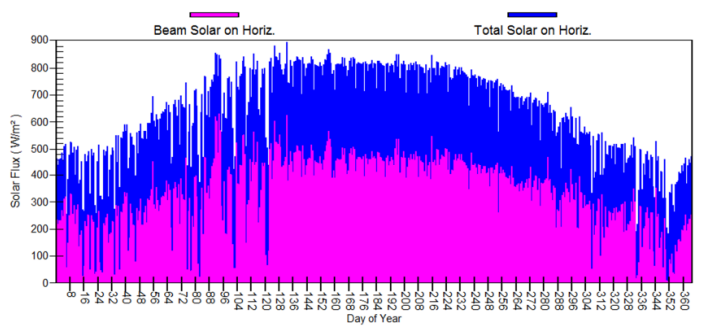

Fig. 8. HAP simulated solar profile for Arar (zone 2), weather file IWEC2 SAU_ARAR_403570_IW2.CSV

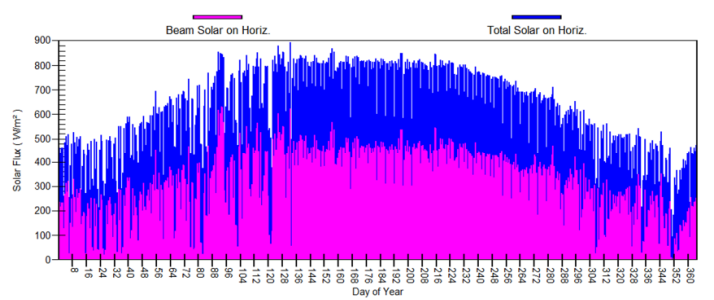

Fig. 9. HAP simulated solar profile for Turaif (zone 3), weather file IWEC2: SAU_TURAIF_403560_IW2

Three insulation materials were used: extruded polystyrene (PLS), polyurethane (PLU) and rock wool (RW). Minimum 
insulation thickness is calculated based on the overall heat transfer coefficient for wall and roof structures using (1)-(3). Three wall structures were studied to install thermal insulation: DWS, EIFS, and IIFS as shown in Table VI and Figures 10 and 11.

TABLE VI. MINIMUM THERMAL INSULATION THICKNESS*

\begin{tabular}{|c|c|c|c|c|}
\hline \multicolumn{2}{|c|}{ Climate Zone } & Zone 1 & Zone 2 & Zone 3 \\
\hline \multirow{3}{*}{ PLS } & DWS & 70 & 60 & 50 \\
\cline { 2 - 5 } & EIFS/IIFS & 80 & 70 & 60 \\
\cline { 2 - 5 } & Roof & 130 & 110 & 100 \\
\hline \multirow{3}{*}{ PLU } & DWS & 60 & 50 & 40 \\
\cline { 2 - 5 } & EIFS/IIFS & 65 & 55 & 45 \\
\cline { 2 - 5 } & Roof & 100 & 85 & 75 \\
\hline \multirow{3}{*}{ RW } & DWS & 100 & 85 & 70 \\
\cline { 2 - 5 } & EIFS/IIFS & 110 & 90 & 80 \\
\cline { 2 - 5 } & Roof & 185 & 155 & 135 \\
\hline
\end{tabular}

The analysis of thermal insulation thicknesses that are compliant with SBC 602 for the three climatic zones shows that PLU has the minimum thickness as shown in Figure 10. Its thicknesses for DWS are $60 \mathrm{~mm}, 50 \mathrm{~mm}, 40 \mathrm{~mm}$ for zones 1,2 and 3 respectively, while its thicknesses for EIFS/IIFS are $65 \mathrm{~mm}, 55 \mathrm{~mm}$ and $45 \mathrm{~mm}$. In roof thermal insulation, PLU shows minimum thickness of about $100 \mathrm{~mm}, 85 \mathrm{~mm}$, and $75 \mathrm{~mm}$ for zones 1, 2 and 3 respectively, as shown in Figure 11. Further calculation is conducted to compute the overall costs of installing the insulation material within the wall structure. The thermal insulation costs including material and labor are generated based on 2018 average market prices and previous experience (Table VII).

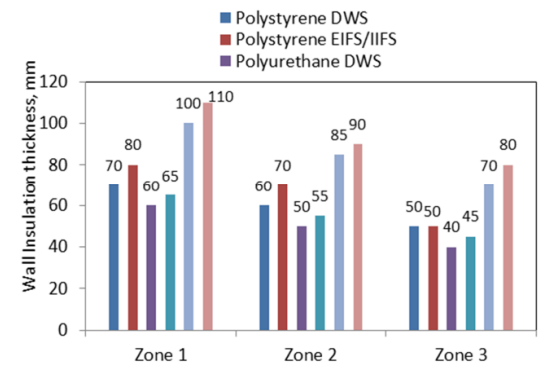

Fig. 10. Minimum wall insulation thickness in compliance with SBC602

In all zones, EIFS and IIFS systems show the lowest overall cost utilizing PLU as insulation material. DWS has the highest cost for the three zones compared to EIFS/IIFS. Also, considering the overall wall thickness, DWS has the highest wall thickness ranging from $390 \mathrm{~mm}$ to $460 \mathrm{~mm}$ for all cases, while the EIFS/IIFS thickness ranges from $250 \mathrm{~mm}$ to $320 \mathrm{~mm}$. The system of EIFS with PLU as insulation material has the lowest cost option with the best thermal efficiency and hence this system has been used for lateral examination by HAP. The designed HVAC loads for base-case building and energy efficient building show a considerable saving in thermal loads due to using thermal insulation and other measures. The loads for the base case building, designed HVAC $\left(\mathrm{W} / \mathrm{m}^{2}\right)$ for each zone are $167.7,153.1$ and 141.9 respectively. For the energy efficient building, the designed HVAC $(\mathrm{W} / \mathrm{m} 2)$ are $60.4,58.3$ and 45.8 for each zone. The saving percentage for $\mathrm{z} 1, \mathrm{z} 2$ and $\mathrm{z} 3$ is: $65.6 \%, 61.8 \%$ and $67.7 \%$ respectively. Details of HVAC loads for the three zones are presented in Figure 12. HVAC monthly simulated consumptions for base case building and energy efficient building are presented in Figure 13, while the saving in installed HVAC capacity and saving in HVAC annual consumption are illustrated in Figure 14. A simple economic calculation is made to compute the average payback period for the system that costs the least (i.e EIFS \& PLU) based on assumption interest rate of $3 \%$, lifetime of 20 years, and 2018 material prices. The results range from 3.3 to 4.2 years for the three zones as presented in Figure 15.

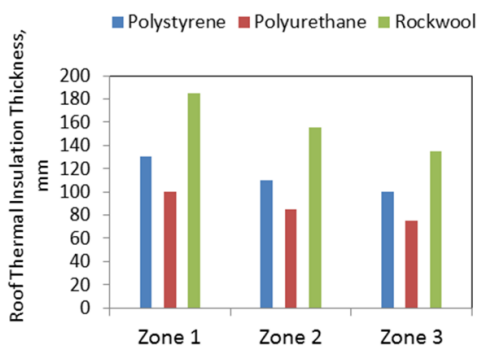

Fig. 11. Minimum roof insulation thickness in compliance with SBC602

TABLE VII. OVERALL COSTS

\begin{tabular}{|c|c|c|}
\hline & DWS, US\$/m $\mathbf{m}^{2}$ & EIFS/IIFS, US\$ $/ \mathbf{m}^{2}$ \\
\hline & \multicolumn{2}{|r|}{ PLS } \\
\hline Zone 1 & 32.49 & 28.32 \\
\hline Zone 2 & 29.41 & 25.24 \\
\hline \multirow[t]{2}{*}{ Zone 3} & 27.49 & 23.32 \\
\hline & \multicolumn{2}{|c|}{ PLU } \\
\hline Zone 1 & 28.72 & 24.57 \\
\hline Zone 2 & 26.15 & 21.99 \\
\hline \multirow[t]{2}{*}{ Zone 3} & 24.18 & 20.02 \\
\hline & \multicolumn{2}{|c|}{ RW } \\
\hline Zone 1 & 43.78 & 39.65 \\
\hline Zone 2 & 38.74 & 33.56 \\
\hline Zone 3 & 34.98 & 30.2 \\
\hline
\end{tabular}

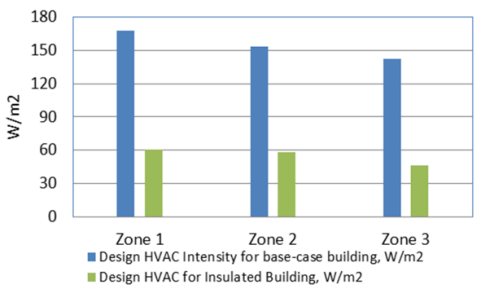

Fig. 12. Designed HVAC loads for base-case and energy efficient building

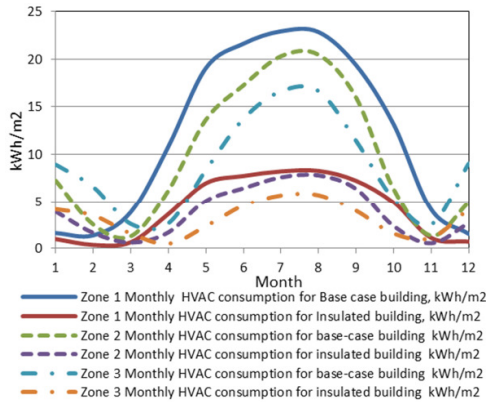

Fig. 13. Simulated monthly HVAC consumption per building $\mathrm{m}^{2}$ for basecase and energy efficient building 


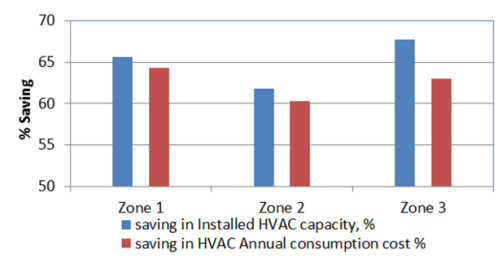

Fig. 14. Saving percentage in HVAC installed capacities and annual consumption for base-case and energy efficient building

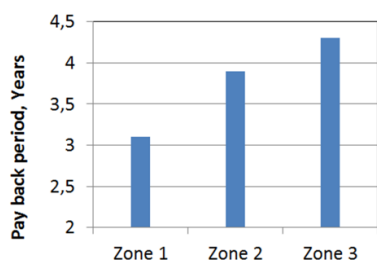

Fig. 15. Pay-back period for PLU on EIFS wall structure

\section{CONCLUSIONS}

It is concluded that EIFS is the most appropriate method of architectural installation of thermal insulation, meeting the minimum requirements of the energy efficiency code in terms of continuous insulation for the building envelope and elimination of thermal bridges. When studying different insulation materials, polyurethane was found the most cost effective while having high thermal efficiency. EIFS utilizing PLU is used by HAP for a comparison study between base-case and energy efficient buildings. HVAC loads and annual energy consumption were designed and simulated and the savings were calculated and listed. Also, the payback periods were calculated for the three climatic zones of SA. EIFS utilizing PLU is selected for economic analysis and shows a promising payback period (form 3.3 to 4.2 years). This would encourage the community for extensive use of thermal insulation in buildings. Further study is recommended for retrofitting of existing (un-insulated) buildings to calculate the cost of converting to energy efficient buildings. In special cases, when retrofitting existing buildings built with highly expensive external finish like granite, marble or even natural stone, the IIFS is recommended but with single restriction to use RW as insulation material, since it has high fire resistance. In this case the insulation cost would be considerably high: $39.65 \mathrm{US} \$ / \mathrm{m}^{2}$, $33.56 \mathrm{US} \$ / \mathrm{m}^{2}$, and $30.2 \mathrm{US} \$ / \mathrm{m}^{2}$ for zones 1,2 , and 3 respectively.

\section{ACKNOWLEDGMENT}

Authors gratefully acknowledge the approval and the support of this research study by the grant no. 461-ENG-20161-6-F from the Deanship of Scientific Research at the Northern Border University, Arar, Saudi Arabia.

\section{REFERENCES}

[1] Electricity \& Cogeneration Regularity Authority, Annual Report, 2017

[2] KSA Vision 2030, www.vision2030.gov.sa

[3] M. A. Mujeebu, O. Alshamrani, "Prospects of energy conservation and management in buildings - The Saudi Arabian scenario versus global trends", Renewable and Sustainable Energy Reviews, Vol. 58, pp. 16471663,2016
[4] General Authority of Statistics, Economic Indicators, available at: https://www.stats.gov.sa/en/node/10127

[5] W. J. A. Lasker, The Impact of Construction and Building Materials on Energy Consumption on Saudi Residential Buildings, PhD Thesis, Heriot Watt University, 2015

[6] F. Yucel, E. Aricioglu, O. Ucan, "Energy Consumption and Economic Growth Nexus: Evidence from Developed Countries in Europe", International Journal of Energy Economics and Policy, Vol. 4, No. 3, pp. 411-419, 2014

[7] E. H. Ahmad, "Cost Analysis and Thickness Optimization of Thermal Insulation Materials Used In Residential Buildings in Saudi Arabia", The 6th Saudi Engineering Conference, Dhahran, Saudi Arabia, December, 2002

[8] Saudi Electricity Company, Optimal Use of Air Conditioner Report, 2015

[9] A. H. M. Khair-El-Din, "Energy Conservation and its Implication for Architectural Design and Town planning in the Hot-arid Areas of Saudi Arabia and the Gulf States", Solar and Wind Technology, Vol. 7, No. 23, pp. 131-138, 1990

[10] National Building Codes Committee, Saudi Building Code Energy Conservation Requirements SBC 602, 2016

[11] SASO Standard 28793/2014 (Thermal Transmittance Values), Saudi Standards, Metrology and Quality Organization (SASO), 2014

[12] Saudi Energy Efiiciency Center, Report of Energy Sectors, 2017

[13] I. A. Al-Mofeez, M. Y. Numan, K. A. Alshaibani, F. A. Al-Maziad, "Review of typical vs. synthesized energy modeling weather files", Journal of Renewable and Sustainable Energy, Vol. 4, No. 1, p. 012702, 2012

[14] ASHRAE, Design Weather Data, 2017

[15] ASHRAE, IWECII International Weather Data for Energy Calculation Version 2, 2017

[16] SASO, ASTM E2110, Standard Terminology for Exterior Insulation and Finish Systems (EIFS), Saudi Standards, Metrology and Quality Organization (SASO), 2011

[17] SASO, ASTM C1154, Standard Terminology for Non-Asbestos FiberReinforced Cement Products) Saudi Standards, Metrology and Quality Organization (SASO), 2012

[18] ASTM C1186-08, Standard Specification for Flat Fiber-Cement Sheets, ASTM International, 2016

[19] British Standards (BS) 476-7:1997, Fire Tests on Building Materials and Structures. Method of Test to Determine the Classification of the Surface Spread of Flame of Products, 1997 